\title{
LIST OF DOCUMENTS OF SPECIAL INTEREST TO ASIA, NOT REPRODUCED IN THE PRESENT VOLUME
}

Text in UNdoc:

UNGA Res. 45/116: Model Treaty on Extradition

A/RES/45/116

UNGA Res. 45/117: Model Treaty on Mutual Assistance in

A/RES/45/117

Criminal Matters

UNGA Res. 45/118: Model Treaty on the Transfer of

Proceedings in Criminal Matters

UNGA Res. 45/119: Model Treaty on the Transfer of

Supervision of Offenders Conditionally Sentence or

Conditionally Released

UNGA Res. 46/57: Measures to Eliminate International

A/RES/46/51

Terrorism

UNGA Res. 46/59: Declaration on Fact-finding by the United

A/RES/46/59

Nations in the Field of the Maintenance of International Peace and Security

Model Agreement between the United Nations and Member States contributing personnel and equipment to UN peace-keeping operations

A/RES/45/118

A/RES/45/119

[Draft] Handbook on the Peaceful Settlement of Disputes between States

Suppl. 33 (A/46/33)

Annex

Framework for a Comprehensive Political Settlement of the Cambodia Conflict (adopted by the Five Permanent Members A/45/472 (or: of the UN Security Council, 28 August 1990). (See supra, S/21689) Appendix p. 275)

Annotated Check-list of Principles on General Rights and Obligations [of States and Regional Economic Organizations, as appropriate in the field of environment and development].

$\mathrm{A} / 46 / 185+$ Corr. 1

(3 June 1991)

(Note by the Secretariat, Prep Com for the UNCED)

Ko Swan Sik et al. (eds.), Asian Yearbook of International Law, 417-418.

(C) 1993 Kluwer Academic Publishers. Printed in the Netherlands.

A/CONF. 151/PC 78

(26 July 1991) 
Principles on General Rights and Obligations [id., supra] (Proposal on behalf of the UN members that are members of the Group of 77)

Principles on General Rights and Obligations [id., supra] (Proposal Japan).

Input from the Asian and Pacific Region to the UNCED, Brazil 1992 (Note by the Secretariat, Prep Com for the UNCED)

Ministerial Declaration on Environmentally Sound and Sustainable Development in Asia and the Pacific, Bangkok 16 October 1990

Beijing Ministerial Declaration on Environment and Development, 19 June 1991

Singapore Resolution on Environment and Development, 18 February 1992

Statement of General Principles of International Environmental Law (adopted by the Special Session of the AALCC on Environment and Development, Islamabad 1 February 1992)

Joint Communiqué of the twenty-third ASEAN Ministerial Meeting, Jakarta $24-25$ July 1990

Joint Communiqué of the twenty-fourth ASEAN Ministerial Meeting, Kuala Lumpur 20 July 1991

The Tehran Declaration: Towards a New Partnership for Development (adopted at the Seventh Ministerial Meetings of the Group of 77, Tehran 16-23 November 1991, in preparation of the eighth session of UNCTAD)

Resolutions adopted at the Twentieth Islamic Conference of Foreign Ministers, Istanbul 4-8 August 1991

Colombo Declaration of the Heads of State or Government of the Member Countries of the South Asian Association for Regional Cooperation (SAARC), 21 December 1991
Text in UNdoc:

A/CONF.151/PC/

WG.III/L.20 and

Rev.1

A/CONF.151/PC/

WG.III/L.22

A/CONF.151/PC/84

A/CONF.151/PC/38

and

A/CONF.151/PC/84

Appendix 2

A/46/293

A/47/118 Appendix

A/CONF.151/

PC/WG.III/5

A/45/389 and

S/21455

$\mathrm{A} / 46 / 323$ and

$\mathrm{S} / 22836$

TD/356

A/46/486 and

S/23055

$A / 47 / 82$ and $S / 23512$

The UN Security Council resolutions on the Iraq-Kuwait War (Nos. 660; 661; 662; 664; $665 ; 666 ; 667 ; 669 ; 670 ; 674 ; 677$; and 678) are reproduced in UN Documents S/RES/661-678 (1990) 